\title{
Microbiological and Nutritional Assessment of Starter-Developed Fermented Tigernut Milk
}

\author{
Sherifah Monilola Wakil*, Oluwatobi Tolu Ayenuro, Kubrat Abiola Oyinlola \\ Department of Microbiology, University of Ibadan, Ibadan, Nigeria \\ Email: 'Shemowak@yahoo.com
}

Received 16 July 2013; revised 16 August 2013; accepted 25 August 2013

Copyright $@ 2014$ by authors and Scientific Research Publishing Inc.

This work is licensed under the Creative Commons Attribution International License (CC BY). http://creativecommons.org/licenses/by/4.0/

\section{Open Access}

\section{Abstract}

Fermented tigernut milk (FTM) was prepared from three different varieties (fresh yellow, big and small dry brown) of tigernut (Cyperus esculenta) obtained from Bodija market, Ibadan, Oyo state. Fifty two microbial isolates were obtained from FTM at different fermentation times, 32 of which were on MRS agar, 12 on nutrient agar and 8 on malt extract agar. Lactic acid bacteria were identified as Lactobacillus plantarum (LP), Lactococcus lactis (LC), Lactobacillus brevis, Lactococcus cremoris, Lactobacillus bulgaricus and Lactococcus thermophilus (LT). The non-LAB identified includes E. coli, Bacillus species and Proteus species while the yeasts include Saccharomyces cerevisiae and Candida kefyr. Lactic acid bacteria were found to predominate the total microflora of the FTM with their count ranging between $2.0 \times 10^{4} \mathrm{cfu} / \mathrm{ml}$ to $2.0 \times 10^{8} \mathrm{cfu} / \mathrm{ml}$. Microbiological examination revealed that the FTM was safe for consumption as non-LAB counts were below the limit of acceptance which is $\mathbf{2 . 0} \times \mathbf{1 0}^{5} \mathrm{cfu} / \mathrm{ml}$ for dairy milk by Codex Alimentarius Commission. The quantity of lactic acid produced by the LAB isolates ranged between $0.86 \mathrm{~g} / \mathrm{l}-2.86 \mathrm{~g} / \mathrm{l}$ while that of hydrogen peroxide ranged between $0.16 \mathrm{~g} / \mathrm{l}-0.51 \mathrm{~g} / \mathrm{l}$. Starter cultures were selected based on predominance of isolate, physiological characteristics, quantity of lactic acid and hydrogen peroxide production. The tiger nut varieties were fermented with the following starter combinations LP, LP/LC, LP/LC/LT, LP/LT while the fifth was spontaneously fermented. The nutritional, chemical and sensory properties of the starter fermented tiger nut milk were evaluated. The highest protein content $(24.80 \%)$ was obtained in FTM with mixed cultures of LP/LC/LT while the least $(3.00 \%)$ was obtained in spontaneously fermented milk. There was a significant difference in the FTM varieties. The highest fat content $(9.40 \%)$ was obtained in spontaneously fermented tiger nut milk while the least ( $3.40 \%)$ was found in FTM with mixed cultures of LP/LC/LT. Fermentation decreased the $\mathrm{pH}$ and increased the lactic acid of the starter developed FTM, while sensory evaluation test showed that the FTM with mixed cultures of LP/LC/LT was highly acceptable. In conclusion, an excellent and acceptable FTM can be produced using treatments which comprise of

\footnotetext{
"Corresponding author.
} 
pasteurization at $90^{\circ}$ for 15 minutes, fermentation at $45^{\circ} \mathrm{C}$ for 18 hours using mixed cultures of Lactobacillus plantarum, Lactococcus lactis and Lactococcus thermophilus.

\section{Keywords}

Tigernut Milk; Pasteurization; Fermentation; Starter-Development; Mixed-Culture

\section{Introduction}

Milk has been recognised as an important food for infants and growing children [1]. In developing countries, the cost of dairy milk and their products is prohibitive and this has led to the development of alternative source of milk from plant materials [2]. An inexpensive milk substitute extracted from locally available plant foods like legumes with satisfactory quality and rich in protein could play an important role in protein malnutrition [3], source of producing acceptable nutritious drink [4] and alleviate problem of short food supply [5].

Tigernut (Cyperus esculenta), also known in Nigeria as "Ayaya" in Hausa, "Ofio" in Yoruba and "Akiausa" in Igbo has three varieties (black, yellow and brown) which are underutilized due to lack of information on their nutritional potentials [6]. It can be eaten raw, roasted, dried, baked or be made into milk [7].

Fermentation of tigernuts could produce varieties of milk products such as natural tigernut milk, pasteurized tigernut milk, sterilized tigernut milk, ultra-high temperature tigernut milk, concentrated and condensed tigernut milk [3]. Tigernut milk is a very nutritive and energetic drink both for old and young people [8], rich in energy content (starch, fat, sugars and protein), mineral (phosphorus, potassium) and vitamins E and C [9]. It has enormous health benefits which include prevention of heart attacks, thrombosis, activation of blood circulation and reduction in the risk of colon cancer [10]. It is also suitable for diabetic patients and helps in reducing weight [11].

The nuts are soaked in water, wet milled, sieved, sweetened and flavoured. Soaking is a major unit operation because it can be used to reduce soluble antinutrients such as tannins and polyphenols [12]. Sponteneous fermentation of tigernut milk results from the competitive activities of a variety of contaminating microorganisms. Those best adapted to the substrate and to technical control parameters, eventually dominate the process. The production of metabolites inhibitory to other contaminating organisms may provide additional advantage during fermentation [13].

Milk contains different species of microorganisms in varying numbers and their activity is uncontrolled, thus, uniformity of product is difficult to achieve during fermentation. It is often necessary and desirable to carry out controlled fermentation with specific organisms and this has led to the propagation and selection of known cultures, usually referred to as starter cultures.

Similar to any other milk, principal organisms employed as starter include species of lactic acid bacteria including Streptococcus, Leuconostoc and Lactobacillus which may be a pure or mixed cultures. The proper selection and balance for starter culture are critical for the manufacture of fermented products of desirable texture and flavour. Quality and reproducibility of fermented milks and processes are ensured by using industrial starters, nevertheless, consumers prefer traditional fermented milks since artisanal starters give these products more typical flavours [14].

\section{Materials and Methods}

\subsection{Sample Collection}

Three different varieties of tigernut (yellow, big brown and small brown) were obtained from Bodija market in Ibadan, Oyo state, Nigeria. They were taken to the laboratory in a clean polythene bag for processing and analysis.

\subsection{Preparation and Fermentation of Tigernut Milk}

The nuts were sorted to remove stones, pebbles, dirt materials, rotten stems and broken tubers before rinsing in water to remove adhering soils. It was later rinsed in distilled water and soaked for $6 \mathrm{hrs}$ at $60^{\circ} \mathrm{C}$ to soften the fi- 
bre [15]. $500 \mathrm{mls}$ of warm distilled water was added to $200 \mathrm{~g}$ of tigernut and blended several times with sterile kenwood blender [3]. The mash was filtered through a clean sterile muslin cloth to separate the milk and it was further strained to obtain a fine consistency. The filtered tigernut milk was transferred into a clean container, pasteurized in a water bath at $90^{\circ} \mathrm{C}$ for 15 minutes, cooled to a temperature of $43^{\circ} \mathrm{C}$ and later maintained for 12 hrs [16]. Spontaneous fermentation was carried out for 18 hrs by the natural flora of the milk and sampled 6 hourly for the analysis of the microbial quality, $\mathrm{pH}$, chemical and proximate composition with initial sampling before commencement of active fermentation $(0 \mathrm{hr})$.

\subsection{Microbiological Analysis}

Nutrient agar (NA), De Mann Rogosa and Sharpe (MRS), Malt extract agar (MEA) and Plate count agar (PCA) was used for microbial culturing of aerobic bacteria, lactic acid bacteria, yeast and total viable bacteria respectively. All media were prepared according to the manufacturers specifications and sterilized at $121^{\circ} \mathrm{C}$ for 15 minutes.1ml from appropriate dilutions $\left(10^{4}\right.$ to $\left.10^{9}\right)$ was pour plated on sterile molten agar, swirled and allowed to set. NA and PCA plates were incubated aerobically at $37^{\circ} \mathrm{C}$ for $24 \mathrm{hrs}$, while MRS agar was incubated at $37^{\circ} \mathrm{C}$ for 48 hrs anaerobically and MEA at $30^{\circ} \mathrm{C}$ for 2 - 5 days. After incubation, colonies on each plate were counted, streaked out repeatedly until pure cultures of each was obtained and maintained on appropriate agar slants at $4^{\circ} \mathrm{C}$.

\subsection{Characterization of Isolates}

Bacteria isolates were characterized and identified on the basis of their cultural, morphological, physiological and biochemical properties using Bergeys Manual of Systematic Bacteriology [17]. The yeast isolates were identified according to the methods of Barnett et al. [18].

\subsection{Screening for Potential Starters}

Pre selected starter cultures were screened for the ability to produce antimicrobial compounds (lactic acid and hydrogen peroxide) [19].

\subsection{Preparation of Inoculums}

The pure cultures of LAB (Lactobacillus plantarum, Lactococcus lactis and Lactococcus thermophilus) isolated from spontaneously fermented tigernut milk were used after being screened for their potentials as starters [19]. The LAB culture was inoculated onto fresh MRS agar slants and incubated anaerobically at $30^{\circ} \mathrm{C}$ for $48 \mathrm{hrs}$. After incubation, the culture was covered with $9 \mathrm{ml}$ of sterile distilled water and shaken to disperse the cells. Appropriate dilutions were made and number of cells determined [20]. A $10^{8} \mathrm{cfu} / \mathrm{ml}$ was achieved when checked as viable count on MRS agar. An inoculums size of $2.9 \times 10^{7} \mathrm{cfu} / \mathrm{ml}$ to $3.2 \times 10^{7} \mathrm{cfu} / \mathrm{ml}$ as viable count was used for the production of starter fermented tigernut milk.

\subsection{Laboratory Production of Starter Developed Fermented Tigernut Milk}

Four treatments of each tigernut milk variety mixtures were processed as described during traditional production. The pasteurized and cooled mixtures were inoculated with $1 \%$ washed cells of starter cultures. Fermentation was allowed to occur in fermenting vessels at $45^{\circ} \mathrm{C}$ for $18 \mathrm{hrs}$. Each treatment has an uninoculated vessel as control. Samples were withdrawn for chemical analysis and quantity of lactic acid determination. Each treatment was as follows:

Vessel I-Lactobacillus plantarum (LP)

Vessel II-L. plantarum + Lactococcus lactis (LP/LC)

Vessel III-L. plantarum + L. lactis + Lactococcus thermophilus (LP/LC/LT)

Vessel IV—L. plantarum + L. thermophilus (LP/LT)

Vessel V-Uninoculated (SP)

\subsection{Physicochemical and Proximate Analysis of Fermented Milk}

The $\mathrm{pH}$, titratable acidity and proximate composition (moisture, ash, fat, protein content and total sugar content) 
of each treatment were determined using the method of A.O.A.C. [19].

\subsection{Sensory Evaluation of Starter Fermented Tigernut Milk}

The acceptability of the milk was determined by the evaluation of the sensory qualities (texture, appearance, taste, aroma and overall acceptability). A 10 men panel was set up and the organoleptic assessment evaluated through degree of likeness or preference on an 8 point hedonic scale ranging from 8 indicating like extremely to 1 indicating dislike extremely.

\subsection{Statistical Analysis}

The experimental data was analyzed using Analysis of variance (ANOVA) to determine significance difference between the means and was expressed as mean \pm standard deviation (SD). The level of significance was $\mathrm{P} \leq$ 0.05. The data were analyzed using SPSS version 15.0.

\section{Results}

An increase in the total bacteria count was observed in all milk samples within the first 6 hours of fermentation of unpasteurized samples after which a decline was noticed. The count ranged from $1.3 \times 10^{7} \mathrm{cfu} / \mathrm{ml}$ to $9.6 \times 10^{5}$ $\mathrm{cfu} / \mathrm{ml}$ at different fermentation times. Insignificant count was observed in pasteurized milk samples within the first 12 hours and a decline was noticed thereafter, with the highest in sample A at 6 hours $\left(2.7 \times 10^{8} \mathrm{cfu} / \mathrm{ml}\right)$ and the lowest in B at 24 hours after pasteurization $\left(8.0 \times 10^{4} \mathrm{cfu} / \mathrm{ml}\right)$. Generally, higher microbial load was observed in unpasteurized milk samples than pasteurized as shown in Tables 1 and 2.

Unlike in pasteurized milk samples where increase in fermentation time leads to an increase in LAB load, the lactic acid bacteria count in samples A and B decreases within the first 12 hours, and increases thereafter while it increases as fermentation progresses in sample $\mathrm{C}$ of unpasteurized milk. Pasteurized sample A has the highest count at 24 hours $\left(2.0 \times 10^{8} \mathrm{cfu} / \mathrm{ml}\right)$ while the lowest was recorded in samples A and C at 0 hour $\left(2.0 \times 10^{4}\right.$ $\mathrm{cfu} / \mathrm{ml})$.

Table 1. Microbial count of unpasteurized fermented milk.

\begin{tabular}{|c|c|c|c|c|c|c|c|c|c|c|c|c|c|c|c|}
\hline Sample & A & & & & & B & & & & & C & & & & \\
\hline Time (hr) & 0 & 6 & 12 & 18 & 24 & 0 & 6 & 12 & 18 & 24 & 0 & 6 & 12 & 18 & 24 \\
\hline $\begin{array}{c}\text { Total } \\
\text { bacteria } \\
\text { count }\end{array}$ & $\begin{array}{c}3.0 \times \\
10^{7}\end{array}$ & $\begin{array}{c}2.7 \times \\
10^{8}\end{array}$ & $\begin{array}{c}6.3 \times \\
10^{7}\end{array}$ & $\begin{array}{c}3.5 \times \\
10^{6}\end{array}$ & $\begin{array}{c}9.6 \times \\
10^{5}\end{array}$ & $\begin{array}{c}7.0 \times \\
10^{7}\end{array}$ & $\begin{array}{c}1.7 \times \\
10^{8}\end{array}$ & $\begin{array}{c}1.3 \times \\
10^{7}\end{array}$ & $\begin{array}{c}3.4 \times \\
10^{6}\end{array}$ & $\begin{array}{c}6.2 \times \\
10^{5}\end{array}$ & $\begin{array}{c}5.0 \times \\
10^{7}\end{array}$ & $\begin{array}{c}1.8 \times \\
10^{8}\end{array}$ & $\begin{array}{c}5.2 \times \\
10^{7}\end{array}$ & $\begin{array}{c}3.0 \times \\
10^{6}\end{array}$ & $\begin{array}{c}3.5 \times \\
10^{5}\end{array}$ \\
\hline $\begin{array}{c}\text { Total LAB } \\
\text { count }\end{array}$ & $\begin{array}{c}1.3 \times \\
10^{6}\end{array}$ & $\begin{array}{c}6.8 \times \\
10^{5}\end{array}$ & $\begin{array}{c}6.0 \times \\
10^{5}\end{array}$ & $\begin{array}{c}7.7 \times \\
10^{5}\end{array}$ & $\begin{array}{c}1.4 \times \\
10^{6}\end{array}$ & $\begin{array}{c}2.4 \times \\
10^{6}\end{array}$ & $\begin{array}{c}9.2 \times \\
10^{5}\end{array}$ & $\begin{array}{c}1.0 \times \\
10^{6}\end{array}$ & $\begin{array}{c}2.4 \times \\
10^{6}\end{array}$ & $\begin{array}{c}8.7 \times \\
10^{6}\end{array}$ & $\begin{array}{c}1.5 \times \\
10^{5}\end{array}$ & $\begin{array}{c}6.2 \times \\
10^{5}\end{array}$ & $\begin{array}{c}1.7 \times \\
10^{6}\end{array}$ & $\begin{array}{c}2.3 \times \\
10^{6}\end{array}$ & $\begin{array}{c}5.1 \times \\
10^{6}\end{array}$ \\
\hline Yeast count & $\begin{array}{c}1.0 \times \\
10^{5}\end{array}$ & $\begin{array}{c}2.0 \times \\
10^{2}\end{array}$ & $\begin{array}{c}8.0 \times \\
10^{2}\end{array}$ & $\begin{array}{c}1.1 \times \\
10^{4}\end{array}$ & $\begin{array}{c}1.6 \times \\
10^{4}\end{array}$ & NG & NG & $\begin{array}{c}2.0 \times \\
10^{3}\end{array}$ & $\begin{array}{c}6.2 \times \\
10^{3}\end{array}$ & $\begin{array}{c}1.2 \times \\
10^{4}\end{array}$ & NG & $\begin{array}{c}8.0 \times \\
10^{2}\end{array}$ & $\begin{array}{c}1.0 \times \\
10^{3}\end{array}$ & $\begin{array}{l}4.1 \times \\
10^{3}\end{array}$ & $\begin{array}{c}5.0 \times \\
10^{4}\end{array}$ \\
\hline
\end{tabular}

Key: A—Yellow tigernut milk; B—Big, dry, brown tigernut milk; C—Small, dry, brown tigernut milk; NG—No growth.

Table 2. Microbial count of pasteurized fermented milk.

\begin{tabular}{|c|c|c|c|c|c|c|c|c|c|c|c|c|c|c|c|}
\hline Sample & A & & & & & B & & & & & C & & & & \\
\hline Time (hr) & 0 & 6 & 12 & 18 & 24 & 0 & 6 & 12 & 18 & 24 & 0 & 6 & 12 & 18 & 24 \\
\hline $\begin{array}{c}\text { Total } \\
\text { bacteria } \\
\text { count }\end{array}$ & $\begin{array}{c}4.8 \times \\
10^{6}\end{array}$ & $\begin{array}{c}4.0 \times \\
10^{6}\end{array}$ & $\begin{array}{c}3.8 \times \\
10^{6}\end{array}$ & $\begin{array}{c}2.0 \times \\
10^{5}\end{array}$ & $\begin{array}{c}1.3 \times \\
10^{5}\end{array}$ & $\begin{array}{c}1.9 \times \\
10^{6}\end{array}$ & $\begin{array}{c}1.0 \times \\
10^{6}\end{array}$ & $\begin{array}{c}1.2 \times \\
10^{6}\end{array}$ & $\begin{array}{c}1.8 \times \\
10^{5}\end{array}$ & $\begin{array}{c}8.0 \times \\
10^{4}\end{array}$ & $\begin{array}{c}2.2 \times \\
10^{6}\end{array}$ & $\begin{array}{c}2.0 \times \\
10^{6}\end{array}$ & $\begin{array}{c}1.8 \times \\
10^{6}\end{array}$ & $\begin{array}{c}2.4 \times \\
10^{5}\end{array}$ & $\begin{array}{c}1.1 \times \\
10^{5}\end{array}$ \\
\hline $\begin{array}{c}\text { Total LAB } \\
\text { count }\end{array}$ & $\begin{array}{c}2.0 \times \\
10^{4}\end{array}$ & $\begin{array}{c}7.2 \times \\
10^{5}\end{array}$ & $\begin{array}{c}1.8 \times \\
10^{6}\end{array}$ & $\begin{array}{c}2.5 \times \\
10^{6}\end{array}$ & $\begin{array}{c}2.0 \times \\
10^{8}\end{array}$ & $\begin{array}{c}4.0 \times \\
10^{4}\end{array}$ & $\begin{array}{c}2.5 \times \\
10^{5}\end{array}$ & $\begin{array}{c}7.5 \times \\
10^{5}\end{array}$ & $\begin{array}{c}2.1 \times \\
10^{6}\end{array}$ & $\begin{array}{c}1.8 \times \\
10^{8}\end{array}$ & $\begin{array}{c}2.0 \times \\
10^{4}\end{array}$ & $\begin{array}{c}2.9 \times \\
10^{5}\end{array}$ & $\begin{array}{c}9.2 \times \\
10^{5}\end{array}$ & $\begin{array}{c}1.8 \times \\
10^{6}\end{array}$ & $\begin{array}{r}1.7 \times \\
10^{8}\end{array}$ \\
\hline $\begin{array}{l}\text { Yeast } \\
\text { count }\end{array}$ & $\begin{array}{c}1.0 \times \\
10^{4}\end{array}$ & $\begin{array}{c}2.0 \times \\
10^{4}\end{array}$ & $\begin{array}{c}5.0 \times \\
10^{4}\end{array}$ & $\begin{array}{c}9.0 \times \\
10^{4}\end{array}$ & $\begin{array}{c}1.0 \times \\
10^{5}\end{array}$ & NG & NG & $\begin{array}{c}1.0 \times \\
10^{4}\end{array}$ & $\begin{array}{c}3.0 \times \\
10^{4}\end{array}$ & $\begin{array}{c}1.3 \times \\
10^{5}\end{array}$ & $\mathrm{NG}$ & $\begin{array}{c}3.0 \times \\
10^{4}\end{array}$ & $\begin{array}{c}2.6 \times \\
10^{5}\end{array}$ & $\begin{array}{c}2.8 \times \\
10^{5}\end{array}$ & $\begin{array}{c}2.9 \times \\
10^{5}\end{array}$ \\
\hline
\end{tabular}

Key: A-Yellow tigernut milk; B—Big, dry, brown tigernut milk; C—Small, dry, brown tigernut milk; NG—No growth. 
Generally, an increase in total yeast count as fermentation time increases was observed in all samples of both pasteurized and unpasteurized milk.

The $\mathrm{pH}$ of the fermenting tigernut milk decreased with increase in fermentation time (Table 3). The least $\mathrm{pH}$ (4.6) was observed in sample $C$ at 24 hours and the highest in sample A at 6 hours (6.9).

Based on the results of the morphological, physiological and biochemical tests, different LAB and yeast species were identified and their percentage frequency of occurrence showed Lactobacillus plantarum (22.7\%) being the most frequent among lactic bacteria species followed by Lactococcus lactis (18.2\%) and Saccharomyces cerevisiae having the highest (75\%) among yeast species.

The result of the production of antimicrobial compounds was shown in Figures 1 and 2 where the highest lactic acid measured using the total titratable acidity, was observed at 48 hours in all LAB isolates. The highest value was produced by $L$. thermophilus $(2.86 \mathrm{~g} / \mathrm{l})$ while the least was from $L$. cremoris $(0.86 \mathrm{~g} / \mathrm{l})$. L. plantarum, L. thermophilus, L. cremoris and L. lactis had an increase in production as incubation tine increases. The highest quantity of hydrogen peroxide produced was $0.51 \mathrm{~g} / \mathrm{l}$ by L. plantarum and L. thermophilus at $24 \mathrm{hr}$ and $48 \mathrm{hr}$ respectively while $L$. brevis and $L$. cremoris has the least quantity $(0.16 \mathrm{~g} / \mathrm{l})$ at 6 hours.

The $\mathrm{pH}$ and titratable acidity of starter developed fermented milk, using single and combined starters, as illustrated in Tables 4 and 5 showed that there was an increase in lactic acid content and decrease in $\mathrm{pH}$ as fermentation time increases. The least $\mathrm{pH}$ (3.9) was observed in treatments LP and LP/LT of varieties A and B both at 18 hours. The highest $\mathrm{pH}$ for variety A (4.9), B (4.8) and C (4.6) were all recorded in the spontaneously fermented milk and was significantly different $(\mathrm{p}>0.05)$ from their starter fermented product (Table 4). The highest titratable acidity in varieties A (1.8\%), B (1.85\%) and C (1.84\%) were produced from the treatment LP/LC/LT and the least observed in spontaneously fermented milk which was significantly different $(p>0.05)$ from starter produced milk (Table 5).

The analysis of the proximate contents of the unpasteurized milk extracted from the three tigernut varieties as shown on Table 6 revealed that the big fresh yellow tigernut milk (sample A) has the highest moisture content (90.36\%), carbohydrate (8.34\%) and protein content (1.66\%) while the least proximate content was recorded in small dry brown tigernut milk (sample $\mathrm{C})$. These constituents were significantly different $(\mathrm{p}<0.05)$ from each

Table 3. The $\mathrm{pH}$ of fermenting tigernut milk.

\begin{tabular}{cccccc}
\hline Sample & & $\mathbf{p H}$ & & \\
& 0 & 6 & 12 & 24 \\
A & 6.8 & 6.9 & 5.5 & 5.1 \\
B & 6.6 & 6.7 & 5.4 & 5.0 & 5.9 \\
C & 6.5 & 6.5 & 5.5 & 5.0 \\
\hline
\end{tabular}

Key: A—Yellow tigernut milk; B-Big, dry, brown tigernut milk; C—Small, dry, brown tigernut milk.

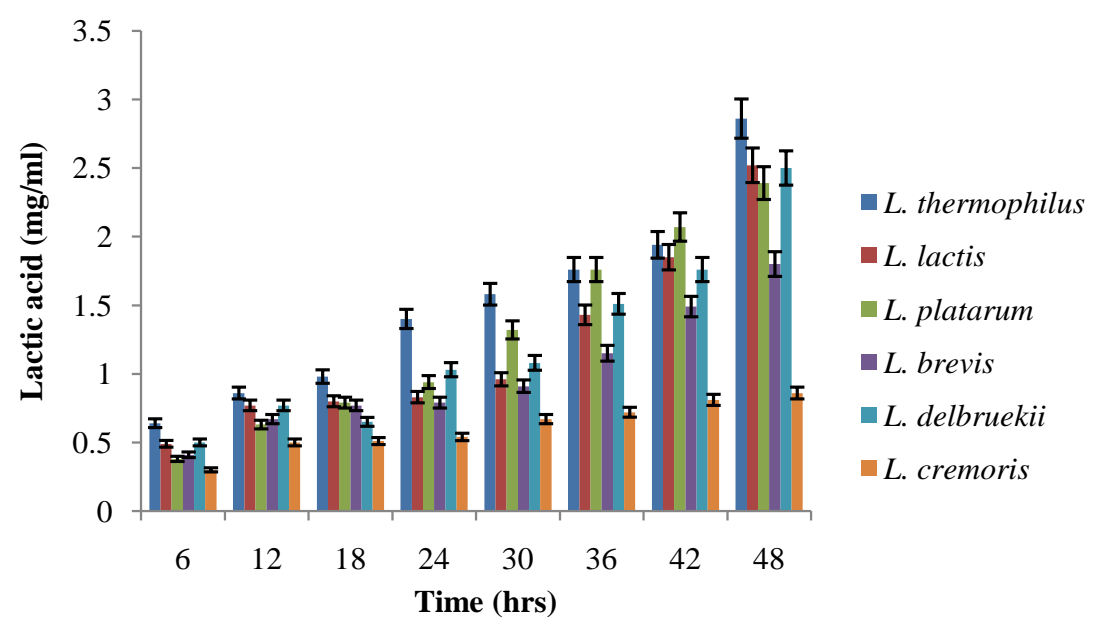

Figure 1. Quantity of lactic acid $(\mathrm{mg} / \mathrm{ml})$ produced by isolated LAB. 


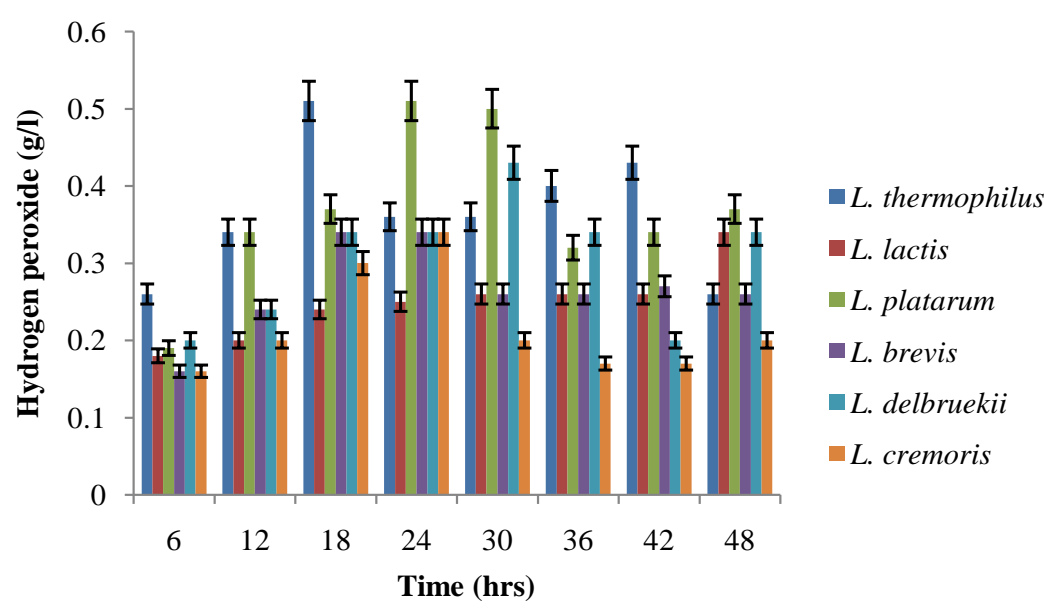

Figure 2. Quantity of hydrogen peroxide (g/l) produced by isolated LAB.

Table 4. The $\mathrm{pH}$ of starter developed fermented tigernut milk.

\begin{tabular}{|c|c|c|c|c|c|c|}
\hline \multirow{3}{*}{$\begin{array}{c}\text { Test } \\
\text { isolates/Treatments }\end{array}$} & \multicolumn{6}{|c|}{ pH } \\
\hline & \multicolumn{2}{|c|}{ A } & \multicolumn{2}{|c|}{ B } & \multicolumn{2}{|c|}{$\mathrm{C}$} \\
\hline & $0 \mathrm{hr}$ & 18 hrs & $0 \mathrm{hr}$ & $18 \mathrm{hrs}$ & $0 \mathrm{hr}$ & 18 hrs \\
\hline SP & $6.8 \pm 0.028^{\mathrm{a}}$ & $4.9 \pm 0.042^{\mathrm{a}}$ & $6.6 \pm 0.028^{b}$ & $4.8 \pm 0.000^{\mathrm{a}}$ & $6.5 \pm 0.042^{b}$ & $4.6 \pm 0.028^{a}$ \\
\hline LP & $6.7 \pm 0.042^{\mathrm{ab}}$ & $3.9 \pm 0.028^{\mathrm{d}}$ & $6.7 \pm 0.042^{\mathrm{a}}$ & $3.9 \pm 0.014^{\mathrm{d}}$ & $6.5 \pm 0.028^{b}$ & $4.1 \pm 0.014^{\mathrm{b}}$ \\
\hline LP/LC & $6.8 \pm 0.042^{\mathrm{a}}$ & $4.2 \pm 0.028^{b}$ & $6.6 \pm 0.042^{\mathrm{b}}$ & $4.1 \pm 0.042^{\mathrm{b}}$ & $6.5 \pm 0.028^{b}$ & $4.1 \pm 0.042^{b}$ \\
\hline LP/LC/LT & $6.8 \pm 0.028^{\mathrm{a}}$ & $4.0 \pm 0.000^{c}$ & $6.7 \pm 0.014^{\mathrm{a}}$ & $4.1 \pm 0.028^{b}$ & $6.5 \pm 0.014^{\mathrm{b}}$ & $4.2 \pm 0.042^{\mathrm{b}}$ \\
\hline $\mathrm{LP} / \mathrm{LT}$ & $6.6 \pm 0.057^{\mathrm{b}}$ & $3.9 \pm 0.042^{\mathrm{d}}$ & $6.6 \pm 0.000^{\mathrm{b}}$ & $4.0 \pm 0.014^{\mathrm{c}}$ & $6.6 \pm 0.042^{\mathrm{a}}$ & $4.1 \pm 0.057^{\mathrm{b}}$ \\
\hline
\end{tabular}

Values are means of three replicates \pm SD. Mean values with similar superscript along the column are not significantly different, $\mathrm{p}<0.05$. Key: AYellow tigernut milk, B-Big, dry, brown tigernut milk, C-Small, dry, brown tigernut milk, SP-Spontaneously fermented, LP-Lactobacillus plantarum, LP/LC—L. plantarum and L. lactis, LP/LC/LT-L. plantarum, L. lactis and Lactococcus thermophilus, LP/LT-L. plantarum and L. thermophilus.

Table 5. Percentage lactic acid produced by starter developed fermented tigernut milk.

\begin{tabular}{ccccccc}
\hline \multirow{2}{*}{$\begin{array}{c}\text { Test } \\
\text { isolates/Treatments }\end{array}$} & \multicolumn{5}{c}{ Lactic acid (\%) } \\
\cline { 2 - 7 } & \multicolumn{2}{c}{ A } & \multicolumn{2}{c}{ B } & C \\
\cline { 2 - 7 } & $0 \mathrm{hr}$ & $18 \mathrm{hrs}$ & $0 \mathrm{hr}$ & $18 \mathrm{hrs}$ & $0 \mathrm{hr}$ & $18 \mathrm{hrs}$ \\
\hline SP & $0.34 \pm 0.0071^{\mathrm{c}}$ & $0.62 \pm 0.0000^{\mathrm{d}}$ & $0.35 \pm 0.0014^{\mathrm{c}}$ & $0.52 \pm 0.0057^{\mathrm{d}}$ & $0.36 \pm 0.0042^{\mathrm{bc}}$ & $0.52 \pm 0.0057^{\mathrm{e}}$ \\
LP & $0.35 \pm 0.0028^{\mathrm{bc}}$ & $0.80 \pm 0.0057^{\mathrm{c}}$ & $0.34 \pm 0.0028^{\mathrm{d}}$ & $0.75 \pm 0.0042^{\mathrm{c}}$ & $0.35 \pm 0.0057^{\mathrm{c}}$ & $0.76 \pm 0.0042^{\mathrm{d}}$ \\
LP/LC & $0.35 \pm 0.0042^{\mathrm{bc}}$ & $1.35 \pm 0.0042^{\mathrm{b}}$ & $0.35 \pm 0.0042^{\mathrm{c}}$ & $0.81 \pm 0.0028^{\mathrm{b}}$ & $0.38 \pm 0.0071^{\mathrm{a}}$ & $0.78 \pm 0.0071^{\mathrm{c}}$ \\
LP/LC/LT & $0.36 \pm 0.0057^{\mathrm{b}}$ & $1.80 \pm 0.0071^{\mathrm{a}}$ & $0.37 \pm 0.0057^{\mathrm{b}}$ & $1.85 \pm 0.0028^{\mathrm{a}}$ & $0.37 \pm 0.0014^{\mathrm{ab}}$ & $1.84 \pm 0.0042^{\mathrm{a}}$ \\
LP/LT & $0.38 \pm 0.0071^{\mathrm{a}}$ & $0.81 \pm 0.0042^{\mathrm{c}}$ & $0.38 \pm 0.0000^{\mathrm{a}}$ & $0.80 \pm 0.0042^{\mathrm{b}}$ & $0.36 \pm 0.0042^{\mathrm{bc}}$ & $0.81 \pm 0.0028^{\mathrm{b}}$ \\
\hline
\end{tabular}

Values are means of three replicates \pm SD. Mean values with similar superscript along the column are not significantly different, $\mathrm{p}<0.05$; Key as in Table 4 above.

other. The highest fat (3.02\%) was observed in sample $\mathrm{C}$ and least fat (0.76\%) in sample A while big dry brown tigernut milk (sample B) has the highest (0.42\%) ash content.

From Table 7, the proximate composition at the end of fermentation of the yellow variety with different combinations of starter culture indicated that, nutritionally, the best protein, fat, moisture and sugar contents was observed in treatment LP/LC/LT. The protein content of treatment LP/LC/LT was the highest (24.8\%) while the least was from the spontaneously fermented milk. The milk sample A5 also has the highest fat, moisture and ash 
Table 6. Proximate composition of unpasteurized tigernut milk varieties.

\begin{tabular}{cccccc}
\hline Tigernut variety & Moisture content \% & Protein \% & Fat \% & Ash \% & Carbohydrate \% \\
\hline A & $90.36 \pm 0.198^{\mathrm{a}}$ & $1.66 \pm 0.156^{\mathrm{a}}$ & $0.76 \pm 0.085^{\mathrm{c}}$ & $0.39 \pm 0.0071^{\mathrm{b}}$ & $8.34 \pm 0.014^{\mathrm{a}}$ \\
B & $87.31 \pm 0.156^{\mathrm{b}}$ & $1.23 \pm 0.113^{\mathrm{b}}$ & $2.19 \pm 0.113^{\mathrm{b}}$ & $0.42 \pm 0.0085^{\mathrm{a}}$ & $8.05 \pm 0.141^{\mathrm{b}}$ \\
C & $86.59 \pm 0.226^{\mathrm{c}}$ & $0.79 \pm 0.127^{\mathrm{c}}$ & $3.02 \pm 0.141^{\mathrm{a}}$ & $0.32 \pm 0.0000^{\mathrm{c}}$ & $7.77 \pm 0.042^{\mathrm{c}}$ \\
\hline
\end{tabular}

Values are means of three replicates \pm SD. Mean values with similar superscript along the column are not significantly different, $\mathrm{p}<0.05$; Key: AYellow tigernut milk; B—Big, dry, brown tigernut milk; C—Small, dry, brown tigernut milk.

Table 7. Proximate composition of pasteurized starter-fermented yellow variety of tigernut milk.

\begin{tabular}{cccccc}
\hline \multirow{2}{*}{ Parameter (\%) } & \multicolumn{5}{c}{ Fermented tigernut milk (yellow variety) } \\
\cline { 2 - 6 } & A1 & A2 & A3 & A4 & A5 \\
\hline Protein & $5.90 \pm 0.012^{\mathrm{d}}$ & $14.0 \pm 0.017^{\mathrm{b}}$ & $24.8 \pm 0.035^{\mathrm{a}}$ & $8.80 \pm 0.006^{\mathrm{c}}$ & $4.20 \pm 0.0012^{\mathrm{e}}$ \\
Fat & $6.00 \pm 0.115^{\mathrm{c}}$ & $6.70 \pm 0.115^{\mathrm{b}}$ & $3.40 \pm 0.058^{\mathrm{e}}$ & $5.10 \pm 0.231^{\mathrm{d}}$ & $9.40 \pm 0.231^{\mathrm{a}}$ \\
Moisture & $80.7 \pm 0.115^{\mathrm{b}}$ & $73.0 \pm 0.173^{\mathrm{d}}$ & $70.0 \pm 0.058^{\mathrm{e}}$ & $76.0 \pm 0.115^{\mathrm{c}}$ & $85.4 \pm 0.023^{\mathrm{a}}$ \\
Ash & $0.12 \pm 0.006^{\mathrm{b}}$ & $0.10 \pm 0.012^{\mathrm{b}}$ & $0.10 \pm 0.006^{\mathrm{b}}$ & $0.10 \pm 0.006^{\mathrm{b}}$ & $0.27 \pm 0.012^{\mathrm{a}}$ \\
Total sugar & $7.28 \pm 0.012^{\mathrm{a}}$ & $6.20 \pm 0.012^{\mathrm{b}}$ & $1.70 \pm 0.173^{\mathrm{e}}$ & $5.70 \pm 0.012^{\mathrm{c}}$ & $5.03 \pm 0.006^{\mathrm{d}}$ \\
\hline
\end{tabular}

Values are means of three replicates $\pm \mathrm{SD}$. Mean values with similar superscript across rows are not significantly different, $\mathrm{p}<0.05$; A1-Yellow variety milk with LP, A2-Yellow variety milk with LP + LC, A3-Yellow variety milk with LP + LC + LT; A4-Yellow variety milk with LP + LT, A5-Spontaneously fermented yellow variety milk.

contents, whereas, it was totally reduced in the milk with starter LP/LC/LT. The proximate composition was significantly different $(\mathrm{p}>0.05)$ among the treatments.

Table 8 shows that the highest fat $(9.10 \%)$, moisture $(83.7 \%)$ and ash $(0.30 \%)$ contents were observed in treatment B5 of the fermented big, dry brown tigernut milk while B3 has the least. Protein content was highest (22.7\%) in the treatment fermented with LP/LC/LT (B3), while its total sugar was the lowest (1.30\%).

Similar to previous result, combination of three LAB starters (C3) recorded the least amounts of fat, moisture, total sugar and highest protein content $(21 \%)$ which was significantly different $(p>0.05)$ from other treatments. The highest fat (6.8\%), moisture (79.7\%), ash (0.27\%) and least protein (3\%) was recorded in the spontaneously fermented small, dry brown tigernut milk (Table 9).

Tables 10-12 showed the result of sensory properties evaluation of freshly prepared fermented tigernut milk from the three varieties using single and combined starter cultures. Sample A3 was rated best for all sensory evaluation with highest overall values. There was no significant difference $(p \leq 0.05)$ in aroma and appearance of all the sample B milk, although the highest mean values for taste, texture and general acceptance was observed in treatment B3. For sample C milk, there was no significant difference $(p \leq 0.05)$ in the aroma, appearance and general acceptance of all treatments, with C3 having the highest mean value for all the sensory attributes.

\section{Discussion}

The identified non-lactic acid bacteria (E. coli, Bacillus species and Proteus species) reported in this study has also been reported by other authors [21] [22]. E. coli has been associated with the contamination of milk and milk products [23]. Researchers have linked the presence of $E$. coli with other enteric pathogens such as Proteus and Bacillus sp [22] [24] [25]. The thermoduric nature of Bacillus spores ensures survival at pasteurization temperatures and hence, their presence in the fermented tigernut milk samples that have been subjected to heat treatment during processing.

The high incidence of LAB species in fermented tigernut milk is in accordance with earlier report by Cogan et al. [26], from lactic acid bacteria of different fermented milk and dairy products. The presence of yeast in the fermenting tigernut milk could be as a result of the substrate which is a plant material as reported by Holzapfel [27].

In the quantitative determination of lactic acid produced, increase in incubation time leads to increase in lactic 
Table 8. Proximate composition of pasteurized starter-fermented big, dry brown variety of tigernut milk.

\begin{tabular}{cccccc}
\hline \multirow{2}{*}{ Parameter (\%) } & \multicolumn{5}{c}{ Fermented tigernut milk (big, dry brown variety) } \\
\cline { 2 - 6 } & B1 & B2 & B3 & B4 & B5 \\
\hline Protein & $5.20 \pm 0.006^{\mathrm{c}}$ & $15.0 \pm 0.115^{\mathrm{b}}$ & $22.7 \pm 0.029^{\mathrm{a}}$ & $4.80 \pm 0.017^{\mathrm{d}}$ & $3.50 \pm 0.023^{\mathrm{e}}$ \\
Fat & $4.10 \pm 0.058^{\mathrm{d}}$ & $6.20 \pm 0.115^{\mathrm{b}}$ & $3.40 \pm 0.029^{\mathrm{e}}$ & $5.90 \pm 0.115^{\mathrm{c}}$ & $9.10 \pm 0.115^{\mathrm{a}}$ \\
Moisture & $78.5 \pm 0.058^{\mathrm{b}}$ & $73.2 \pm 0.115^{\mathrm{c}}$ & $72.4 \pm 0.029^{\mathrm{c}}$ & $78.1 \pm 0.173^{\mathrm{b}}$ & $83.7 \pm 3.151^{\mathrm{a}}$ \\
Ash & $0.10 \pm 0.000^{\mathrm{c}}$ & $0.20 \pm 0.029^{\mathrm{b}}$ & $0.20 \pm 0.012^{\mathrm{b}}$ & $0.10 \pm 0.006^{\mathrm{c}}$ & $0.30 \pm 0.006^{\mathrm{a}}$ \\
Total sugar & $12.1 \pm 0.058^{\mathrm{a}}$ & $5.40 \pm 0.115^{\mathrm{d}}$ & $1.30 \pm 0.029^{\mathrm{e}}$ & $11.1 \pm 0.173^{\mathrm{b}}$ & $6.40 \pm 0.115^{\mathrm{c}}$ \\
\hline
\end{tabular}

Values are means of three replicates \pm SD. Mean values with similar superscript across rows are not significantly different, $\mathrm{p}<0.05$. Code as in Table 7.

Table 9. Proximate composition of starter fermented small, dry brown variety of tigernut milk.

\begin{tabular}{cccccc}
\hline \multirow{2}{*}{ Parameters (\%) } & \multicolumn{5}{c}{ Fermented tigernut milk (small, dry brown variety) } \\
\cline { 2 - 6 } & C1 & C2 & C3 & C4 & C5 \\
\hline Protein & $3.80 \pm 0.006^{\mathrm{d}}$ & $9.00 \pm 0.006^{\mathrm{b}}$ & $21.0 \pm 0.017^{\mathrm{a}}$ & $8.10 \pm 0.017^{\mathrm{c}}$ & $3.00 \pm 0.115^{\mathrm{e}}$ \\
Fat & $4.30 \pm 0.006^{\mathrm{c}}$ & $5.40 \pm 0.006^{\mathrm{b}}$ & $3.90 \pm 0.017^{\mathrm{d}}$ & $4.30 \pm 0.017^{\mathrm{c}}$ & $6.80 \pm 0.012^{\mathrm{a}}$ \\
Moisture & $78.5 \pm 0.198^{\mathrm{b}}$ & $77.3 \pm 0.058^{\mathrm{c}}$ & $72.7 \pm 0.058^{\mathrm{e}}$ & $76.4 \pm 0.058^{\mathrm{d}}$ & $79.7 \pm 0.437^{\mathrm{a}}$ \\
Ash & $0.10 \pm 0.012^{\mathrm{c}}$ & $0.05 \pm 0.017^{\mathrm{d}}$ & $0.19 \pm 0.007^{\mathrm{b}}$ & $0.20 \pm 0.006^{\mathrm{b}}$ & $0.27 \pm 0.006^{\mathrm{a}}$ \\
Total sugar & $13.1 \pm 0.058^{\mathrm{a}}$ & $6.25 \pm 0.006^{\mathrm{d}}$ & $2.20 \pm 0.173^{\mathrm{e}}$ & $11.0 \pm 0.173^{\mathrm{b}}$ & $9.93 \pm 0.012^{\mathrm{c}}$ \\
\hline
\end{tabular}

Values are means of three replicates $\pm \mathrm{SD}$. Mean values with similar superscript across rows are not significantly different, $\mathrm{p}<0.05$. Code as in Table 7.

Table 10. Sensory evaluation of fermented yellow variety tigernut milk.

\begin{tabular}{cccccc}
\hline \multirow{2}{*}{$\begin{array}{c}\text { Sensory } \\
\text { characteristics }\end{array}$} & \multicolumn{5}{c}{ Fermented tigernut milk (yellow variety) } \\
\cline { 2 - 5 } & A1 & A2 & A3 & A4 & A5 \\
\hline Taste & $4.6 \pm 0.16^{\mathrm{b}}$ & $3.1 \pm 0.28^{\mathrm{c}}$ & $5.7 \pm 0.26^{\mathrm{a}}$ & $3.4 \pm 0.22^{\mathrm{c}}$ & $5.2 \pm 0.25^{\mathrm{ab}}$ \\
Aroma & $4.2 \pm 0.39^{\mathrm{bc}}$ & $3.7 \pm 0.30^{\mathrm{c}}$ & $5.5 \pm 0.27^{\mathrm{a}}$ & $5.1 \pm 0.38^{\mathrm{ab}}$ & $4.0 \pm 0.26^{\mathrm{c}}$ \\
Texture & $2.6 \pm 0.22^{\mathrm{b}}$ & $2.7 \pm 0.21^{\mathrm{b}}$ & $3.5 \pm 0.22^{\mathrm{a}}$ & $3.5 \pm 0.17^{\mathrm{a}}$ & $2.0 \pm 0.22^{\mathrm{b}}$ \\
Appearance & $2.5 \pm 0.22^{\mathrm{b}}$ & $2.5 \pm 0.27^{\mathrm{b}}$ & $3.7 \pm 0.33^{\mathrm{a}}$ & $3.2 \pm 0.25^{\mathrm{ab}}$ & $3.0 \pm 0.26^{\mathrm{ab}}$ \\
Acceptability & $3.5 \pm 0.17^{\mathrm{ab}}$ & $3.2 \pm 0.25^{\mathrm{bc}}$ & $4.1 \pm 0.31^{\mathrm{a}}$ & $3.3 \pm 0.21^{\mathrm{b}}$ & $2.6 \pm 0.16^{\mathrm{c}}$ \\
\hline
\end{tabular}

Values are means of three replicates \pm SD. Mean values with similar superscript across rows are not significantly different, $\mathrm{p}<0.05$. Code as in Table 7.

Table 11. Sensory evaluation of fermented big, dry brown variety tigernut milk.

\begin{tabular}{cccccc}
\hline \multirow{2}{*}{$\begin{array}{c}\text { Sensory } \\
\text { characteristics }\end{array}$} & \multicolumn{5}{c}{ Fermented tigernut milk (big, dry brown variety) } \\
\cline { 2 - 6 } & B1 & B2 & B3 & B4 & B5 \\
\hline Taste & $4.7 \pm 0.21^{\mathrm{bc}}$ & $5.1 \pm 0.28^{\mathrm{ab}}$ & $5.5 \pm 0.22^{\mathrm{a}}$ & $4.0 \pm 0.26^{\mathrm{cd}}$ & $3.8 \pm 0.29^{\mathrm{d}}$ \\
Aroma & $3.9 \pm 0.31^{\mathrm{a}}$ & $4.5 \pm 0.22^{\mathrm{a}}$ & $4.8 \pm 0.33^{\mathrm{a}}$ & $4.3 \pm 0.30^{\mathrm{a}}$ & $4.1 \pm 0.28^{\mathrm{a}}$ \\
Texture & $3.6 \pm 0.22^{\mathrm{ab}}$ & $4.2 \pm 0.20^{\mathrm{a}}$ & $4.2 \pm 0.25^{\mathrm{a}}$ & $3.4 \pm 0.22^{\mathrm{b}}$ & $3.1 \pm 0.10^{\mathrm{b}}$ \\
Appearance & $3.3 \pm 0.21^{\mathrm{a}}$ & $3.1 \pm 0.35^{\mathrm{a}}$ & $3.8 \pm 0.33^{\mathrm{a}}$ & $3.4 \pm 0.27^{\mathrm{a}}$ & $3.1 \pm 0.23^{\mathrm{a}}$ \\
Acceptability & $3.1 \pm 0.35^{\mathrm{a}}$ & $4.2 \pm 0.20^{\mathrm{a}}$ & $4.3 \pm 0.26^{\mathrm{a}}$ & $3.9 \pm 0.35^{\mathrm{ab}}$ & $3.5 \pm 0.17^{\mathrm{ab}}$
\end{tabular}

Values are means of three replicates \pm SD. Mean values with similar superscript across rows are not significantly different, $\mathrm{p}<0.05$. Key as in Table 7. 
Table 12. Sensory evaluation of fermented yellow variety tigernut milk.

\begin{tabular}{cccccc}
\hline \multirow{2}{*}{$\begin{array}{c}\text { Sensory } \\
\text { characteristics }\end{array}$} & \multicolumn{5}{c}{ Fermented tigernut milk (small, dry brown variety) } \\
\cline { 2 - 5 } & $\mathrm{C} 1$ & $\mathrm{C} 2$ & $\mathrm{C} 3$ & $\mathrm{C} 4$ & C5 \\
\hline Taste & $4.6 \pm 0.22^{\mathrm{a}}$ & $4.8 \pm 0.25^{\mathrm{a}}$ & $5.0 \pm 0.26^{\mathrm{a}}$ & $3.7 \pm 0.21^{\mathrm{b}}$ & $4.6 \pm 0.31^{\mathrm{a}}$ \\
Aroma & $4.6 \pm 0.37^{\mathrm{a}}$ & $4.8 \pm 0.33^{\mathrm{a}}$ & $5.1 \pm 0.31^{\mathrm{a}}$ & $4.5 \pm 0.27^{\mathrm{a}}$ & $4.3 \pm 0.33^{\mathrm{a}}$ \\
Texture & $3.9 \pm 0.18^{\mathrm{d}}$ & $4.2 \pm 0.25^{\mathrm{bc}}$ & $4.9 \pm 0.23^{\mathrm{a}}$ & $3.9 \pm 0.23^{\mathrm{d}}$ & $4.6 \pm 0.22^{\mathrm{ab}}$ \\
Appearance & $4.1 \pm 0.38^{\mathrm{a}}$ & $4.1 \pm 0.28^{\mathrm{a}}$ & $4.6 \pm 0.16^{\mathrm{a}}$ & $4.2 \pm 0.25^{\mathrm{a}}$ & $4.4 \pm 0.22^{\mathrm{a}}$ \\
Acceptability & $4.3 \pm 0.21^{\mathrm{a}}$ & $4.1 \pm 0.28^{\mathrm{a}}$ & $4.3 \pm 0.21^{\mathrm{a}}$ & $4.2 \pm 0.25^{\mathrm{a}}$ & $4.1 \pm 0.18^{\mathrm{a}}$ \\
\hline
\end{tabular}

Values are means of three replicates \pm SD. Mean values with similar superscript across rows are not significantly different, $\mathrm{p}<0.05$. Key as in Table 7.

acid produced. L. thermophilus produced the highest quantity at 48 hrs, followed by L. lactis and L. plantarum. The difference in acidifying properties may be ascribed to the specificity of the strain and the species, as reported in many studies [28]-[31]. Badis et al. [31] explained these differences by linking the acidification activity of each strain to its capacity to use medium substrates. It was reported that the ability of a high acid production has been demanded for lactic cultures to be used as starter cultures for dairy fermentation technology [32].

Fermentation was observed to decrease the $\mathrm{pH}$ and increase the titratable acidity of the starter fermented tigernut milk. This could be due to the dominance of LAB in the fermentation environment which degrades carbohydrates to simple sugars, resulting in acidification with accordance to the work done by Wakil and Onilude [33] in fermentation of cereal weaning food fortified with cowpea. The $\mathrm{pH}$ values of fermented tigernut milk produced with different varieties recorded in this study ranged between 3.90 and 4.25, and according to Reed [34], a good quality yoghurt (also a fermented milk product) should have a pH of 4.15.

Fermentation, compared with other processing methods such as roasting, cooking etc, has been found to increase the nutritional value of foods [35]-[38]. In this study, the use of starter resulted in an improved nutritional value of the milk as compared with the spontaneously fermented samples. It was established that the use of starter both singly and in combination affects the proximate composition of the fermented milk. The protein content of milk varieties produced with combined starter of Lactobacillus plantarum, Lactococcus lactis and Lactococcus thermophilus was observed to be higher than 8.07\% previously reported by Belewu and Belewu [9]. Also, the high fat content of some fermented milk products was similar to that reported by Belewu et al. [39], but however, high compared to the 8\% standard for dairy milk [40] [41] and 5.3\% reported by Ukwuru and Ogbodo [3]. Belewu and Belewu [9] reported that total energy value of milk is from the fat content hence, higher fat content is an indication of more total energies available.

All starter developed milk of the three varieties had high moisture content between $70.0 \%$ and $80.0 \%$. This could affect the stability and safety of milk with respect to microbial growth and proliferation, therefore, the product requires cold storage in agreement with the work of Ukwuru and Ogbodo [3].

The increase in the protein and fat content of pasteurized fermented milk as compared to the unpasteurized in Table 8 could be attributed to the concentration of the constituents during pasteurization brought about by loss of moisture and reduction/destruction of certain protease and lipase inhibitors which form complexes with protein and makes them unavailable during hydrolysis as it was observed and reported that pasteurized fermented tigernut milk was reflected notably by increase in the protein content [42].

Despite the significant difference in sensory quality of some fermented tigernut milk from the three varieties, all the product samples were generally acceptable to the penalists. Similar works carried out on tigernut milk [43] [44] recorded high acceptability of the milk. Although, from the figures obtained however, little or no difference exists in all the sensory attributes between the samples, the level of acceptance of the tigernut milk produced from the three varieties using starter combination Lactobacillus plantarum, Lactococcus lactis and Lactococcus thermophilus is still very high.

The aroma produced may be due to the formation of acetaldehyde and other aromatic compounds resulting from the anaerobic breakdown of carbohydrates by relevant microbes [16]. Pasteurization modify milk protein so as to enhance proper viscosity and gelatinization of the product [34] and this could account for the uniformity and smoothness in body texture of all products as observed in this study. 


\section{Conclusions}

In conclusion, lactic acid fermentation processes contributes towards the safety, nutritional value and general acceptability of tigernut milk, thus, this study strengthens the position of starter developed tigernut milk as good supplier of protein and moderate fat. It also revealed that pasteurization and fermentation improved the microbial, nutritional and chemical qualities of the products. Microbiological examination showed that all pasteurized fermented milk was safe for consumption. The yellow variety tigernut milk pasteurized at $90^{\circ} \mathrm{C}$ for 15 minutes and fermented with combined three lactic starter cultures (Lactobacillus plantarum, Lactococcus lactis and Lactococcus thermophilus) at $45^{\circ} \mathrm{C}$ for 18 hours resulted in the best quality milk compared to other varieties and starters.

It has been reported that lower temperature slows down chemical reactions, enzyme actions and microbial growth [45]; it is therefore recommended that when tigernut milk is not to be served immediately, it should be stored at low temperatures (i.e. in the refrigerator) so as to prevent the growth of spoilage organisms and maintain the quality of the milk.

\section{References}

[1] Obizoba, I.C. and Anyika, J.U. (1995) Nutritive Value of Baobab Milk (Adansonia digitata), Hungary Rice, Acha (Digitana exillis) Flour. Plant Foods for Human Nutrition, 48, 156-165.

[2] Singh, T. and Baius, G.S. (1988) Grain Extract-Milk Beverage Processing and Physicochemical Characteristics. Journal of Food Science, 53, 1387-1390. http://dx.doi.org/10.1111/j.1365-2621.1988.tb09283.x

[3] Ukwuru, M.U. and Ogbodo, A.C. (2011) Effect of Processing Treatment on the Quality of Tiger Nut Milk. Pakistan Journal of Nutrition, 10, 95-100. http://dx.doi.org/10.3923/pin.2011.95.100

[4] Hankus, R.W. and Sarret, H.P. (1967) Methods of Comparing Protein Quality of Soybean Infant Formulas in Rat. Journal of Nutrition, 91, 213-216.

[5] Reddy, N.S., Waghmare, S.Y. and Pande, V. (1990) Formulation and Evaluation of Homemade Weaning Mixes Based on Local Foods. Food Nutrition Bulletin, 12, 138-140.

[6] Omode, A., Fatoki, O. and Olaogun, K.A. (1995) Physicochemical Properties of Some Underexploited and Non-Conventional Oil Seeds. Journal of Agriculture and Food Chemistry, 11, 50-53.

[7] Oladele, A.K. and Aina, J.O. (2007) Chemical Composition and Functional Properties of Flour Produced from Two Varieties of Tiger Nut (Cyperus esculenta). African Journal of Biotechnology, 6, 2473-2476.

[8] Abaejoh, R., Djomdi, I. and Ndojouenkeu, R. (2006) Characteristics of Tiger Nut (Cyprus esculentus) Tubers and Their Performance in the Production of a Milky Drink. Journal of Food Processing and Preservation, 30, 145-163. http://dx.doi.org/10.1111/j.1745-4549.2006.00056.x

[9] Belewu, M.A. and Belewu, K.Y. (2007) Comparative Physicochemical Evaluation of Tiger Nut, Soy Bean and Coconut Milk Sources. International Journal of Agriculture Biology, 9, 785-787.

[10] Adejuyitan, J.A., Otunla, E.T., Akande, E.A., Bolarinwa, I.F and Oladokun, F.M. (2009) Some Physicochemical Properties of Flour Obtained from Fermentation of Tiger Nut (Cyperus esculentus) Sourced from a Market in Ogbomoso, Nigeria. African Journal of Food Science, 3, 51-55.

[11] Borges, O., Gonclaves, B., Sgeoeiro, L., Correeia, P. and Silva, A. (2008) Nutritional Quality of Chestnut Cultivars from Portugal. Food Chemistry, 106, 976-984. http://dx.doi.org/10.1016/j.foodchem.2007.07.011

[12] Onwuka, G.I. (2006) Soaking, Boiling and Antinutritive Factors in Pigeon Pea (Cajanus cajan) and Cowpea (Vigna unguiculata). Journal of Food Processing and Preservation, 30, 616-630. http://dx.doi.org/10.1111/j.1745-4549.2006.00092.x

[13] Holzapfel, W.H. (2000) Appropriate Starter Culture Technologies for Small Scale Fermentation in Developing Countries. International Journal of Food Microbiology, 5, 19-212.

[14] Wouters, J.T., Ayad, E.H., Hugenholtz, J. and Smit, G. (2002) Microbes from Raw Milk for Fermented Dairy Products. International Dairy Journal, 12, 91-109. http://dx.doi.org/10.1016/S0958-6946(01)00151-0

[15] Djomdi, R.A.E. and Ndjouenkeu, R. (2006) Characteristics of Tiger Nut (Cyperus-esculentus) Tubers and Their Performance in the Production of a Milky Drink. Journal of food Preservation, 30, 145-163.

[16] Rita, E.S. (2009) The Use of Tiger Nut (Cyperus esculentus), Cow Milk and Their Composite as Substrate for Yoghurt Production. Pakistan Journal of Nutrition, 6, 755-758.

[17] Holt, J.G., Kreig, N.G., Peter, H.A., Sneath, S.T. and Williams, S.T. (2000) Bergeys Manual of Systemic Bacteriology 
9th Edition, Lippincott Williams and Wilkins Publisher, 175-201,527-528.

[18] Barnett, J.A., Payne, R.W. and Yarrow, D. (2000) Yeast Characteristics and Identification. Cambridge University Press, London, 100-201.

[19] A.O.A.C. (2000) Official Methods of Analysis. Association of Official Analytical Chemist, Washington D.C.

[20] Rodriguez-Tudela, J.L., Chrysanthou, E., Evangelia, P., Juan, M., David, W.D. and Manuel, C.E. (2003) Inter Laboratory Evaluation of Haemocytometer Method of Inoculums Preparations for Testing Antifungal Susceptibility of Filamentous Fungi. Journal of Clinical Microbiology, 41, 5236-523. http://dx.doi.org/10.1128/JCM.41.11.5236-5237.2003

[21] Onovo, J.C. and Ogaraku, A.O. (2007) Studies on Some Microorganisms Associated with Exposed Tigernut (Cyperus esculentus L.) Milk. Journal of Biological Sciences, 7, 1548-1550. http://dx.doi.org/10.3923/jbs.2007.1548.1550

[22] Adesiyun, A.A. Webb, L. and Rahaman, S. (1995) Microbiological Quality of Raw Cow’s Milk at Collection Centers in Trinidad. Journal of Food Protection, 58, 139-146.

[23] Kulshrestha, S.B. (1990) Prevalence of Enteropathogenic Serogroups of E. coli in Milk Products Samples from Bareilly and Their Multiple Drug Resistance. Industrial Journal Dairy Science, 43, 373-378.

[24] Van den Berg, J.C.T. (1988) Dairy Technology in the Tropics and Sub-Topics. Centre for Agricultural Publishing and Documentation, Wegeningen.

[25] Smoot, L.M. and Pierson, M.D. (1997) Indicator Microorganisms and Microbiological Criteria. In: Doyle, M.P., Beuchat L.R. and Montville T.J., Eds., Food Microbiology: Fundamentals and Frontiers, American Society for Microbiology, Washington DC, 66-80.

[26] Cogan, T.M. Barbosa, M., Beuvier, E., Bianchi-Salvadori, B., Cocconcelli, P.S., Fernandes, I., Gomez, J., Gomez, R., Kalantzopoulos, G., Ledda, A., Medina, M., Rea, M.C. and Rodriquez, E. (1997) Characterization of the Lactic Acid Bacteria in Artisanal Dairy Products. Journal of Dairy Research, 64, 409-421. http://dx.doi.org/10.1017/S0022029997002185

[27] Holzapfel, W.H. (1997) Use of Starter Cultures in Fermentation on a Household Scale. Food Control, 8, 241-258. http://dx.doi.org/10.1016/S0956-7135(97)00017-0

[28] Spinnler, H.E. and Corrieu, G. (1989) Automatic Method to Quantify Starter Activity Based on pH Measurement. Journal of Dairy Research, 56, 755-764. http://dx.doi.org/10.1017/S0022029900029332

[29] Beal, C. and Corrieu, G. (1994) Viability and Acidification Activity of Pure and Mixed Starters of Streptococcus Salivarius spp. Thermophilu 404 and Lactobacillus delbrueckii spp. bulgaricus 398 at the Different Steps of Their Production. Lebensmittel-Wissenschaft and -Technologie, 27, 86-92.

[30] Xanthopoulos, V., Petridis, D. and Tzanetakis, N. (2001) Characterization and Classification of Streptococcus thermophiles and Lactobacillus delbrueckii subsp. Bulgaricus Strains Isolated from Traditional Greek Yogurts. Journal of Food Science, 66, 747-752. http://dx.doi.org/10.1111/j.1365-2621.2001.tb04632.x

[31] Badis, A., Guetarni, D., Moussa Boudjemaa, B., Henni, D.E. and Kihal, M. (2004) Identification and Technological Properties of Lactic Acid Bacteria Isolated from Raw Goat Milk of Four Algerian Races. Food Microbiology, 21, 579588. http://dx.doi.org/10.1016/j.fm.2003.11.006

[32] Buckenhuskes, H.J. (1993) Selection Criteria for Lactic Acid Bacteria to Be Used as Starter Cultures for Various Food Commodities. FEMS Microbiological Review, 12, 253-272. http://dx.doi.org/10.1016/0168-6445(93)90067-J

[33] Wakil, S.M. and Onilude A.A. (2011) Time Related Total Lactic Acid Bacteria Population Diversity and Dominance in Cowpea-Fortified Fermented Cereal-Weaning Food. African Journal of Biotechnology, 10, 887-895.

[34] Reed, G. (1982) Prescott and Dunn’s Industrial Microbiolog. 4th Edition, Macmilian Publisher, London, 146-173.

[35] Paredes-Lopez, O. and Harry, G.I. (1988) Food Biotechnology Review: Traditional Solid-State Fermentations of Plant Raw Materials-Application, Nutritional Significance and Future Prospects. CRC Critical Reviews in Food Science and Nutrition, 27, 159-187. http://dx.doi.org/10.1080/10408398809527483

[36] Adams, M.R. (1990) Topical Aspects of Fermented Foods. Trends in Food Science and Technology, 1, 141-144. http://dx.doi.org/10.1016/0924-2244(90)90111-B

[37] Obizola, I.C. and Atii, J.V. (1991) Effect of Soaking, Sprouting, Fermentation and Cooking on Nutrient Composition and Some Anti-Nutritional Factors of Sorghum Seeds. Plants Foods for Human Nutrition, 41, 203-212. http://dx.doi.org/10.1007/BF02196388

[38] Aletor, V.A. (1993) Cyanide in Gari II. Assessment of Some Aspect of the Nutrition, Biochemistry and Haematology of the Rats Fed Garri Containing Varying Residual Cyanide Levels. International Journal of Food Science and Nutrition, 44, 289-295. http://dx.doi.org/10.3109/09637489309017448.

[39] Belewu, M.A., Belewu, K.Y. and Bamidele, R.A. (2010) Cyper-Coconut Yoghurt: Preparation, Compositional and Organoleptic Qualities. African Journal of Food Science and Technology, 1, 010-012.

[40] FAO/WHO (2002) Milk and Milk Products. Joint FAO/WHO Food Standards Programme. CODEX Alimentarius 
Commossion, 42.

[41] FAO/WHO (2002) Joint FAO/WHO Expert Report on Diet, Nutrition and the Prevention of Chronic Diseases. Food and Nutrition Bulletin, 24, 255-256.

[42] Eka, C.U. and Ohaba, J.A. (1977) Microbial Examination of Fulani Milk (Nono) and Butter (Manshanu). Nigeria Journal of Science, 11, 113-122.

[43] Belewu, M.A. and Abodunrin, O.A. (2006) Preparation of Kunnu from Unexploited Rich Food Source: Tigernut (Cyperus esculentus). World Journal of Diary and Food Sciences, 1, 19-21.

[44] Ukwuru, M.U., Omachona, L.J. and Onokah, N. (2008) Production and Quality Assessment of Tiger Nut (Cyperus esculentus) Imitation Milk during Storage. Journal of Food Science and Technology, 2, 180-182.

[45] Koffi, M.E. (1990) Local Packaging of Food in Ghana. Food and Nutrition Bulletin. The United Nations University, Tokyo. 